\title{
Ion Channel Function of Aquaporin-1 Natively Expressed in Choroid Plexus
}

\author{
Daniela Boassa, ${ }^{1}$ W. Daniel Stamer, ${ }^{2}$ and Andrea J. Yool ${ }^{3}$ \\ ${ }^{1}$ Program in Neuroscience, ${ }^{2}$ Department of Ophthalmology and Vision Science and Department of Pharmacology, and ${ }^{3}$ Departments of Physiology and \\ Pharmacology and Arizona Research Labs Division of Neurobiology, University of Arizona, Tucson, Arizona 85724
}

Aquaporins are known as water channels; however, an additional ion channel function has been observed for several including aquaporin-1 (AQP1). Using primary cultures of rat choroid plexus, a brain tissue that secretes CSF and abundantly expresses AQP1, we confirmed the ion channel function of AQP1 and assessed its functional relevance. The cGMP-gated cationic conductance associated with AQP1 is activated by an endogenous receptor guanylate cyclase for atrial natriuretic peptide (ANP). Fluid transport assays with confluent polarized choroid plexus cultures showed that AQP1 current activation by $4.5 \mu \mathrm{M}$ ANP decreases the normal basal-to-apical fluid transport in the choroid plexus; conversely, AQP1 block with $500 \mu \mathrm{M} \mathrm{Cd}{ }^{2+}$ restores fluid transport. The cGMP-gated conductance in the choroid plexus is lost with targeted knockdown of AQP1 by small interfering RNA (siRNA), as confirmed by immunocytochemistry and whole-cell patch electrophysiology of transiently transfected cells identified by enhanced green fluorescent protein. The properties of the current (permeability to $\mathrm{Na}^{+}, \mathrm{K}^{+}, \mathrm{TEA}^{+}$, and $\mathrm{Cs}^{+}$; voltage insensitivity; and dependence on cGMP) matched properties characterized previously in AQP1-expressing oocytes. Background $\mathrm{K}^{+}$and $\mathrm{Cl}^{-}$currents in the choroid plexus were dissected from AQP1 currents using Cs-methanesulfonate recording salines; the background currents recorded in physiological salines were not affected by AQP1-siRNA treatment. These results confirm that AQP1 can function as both a water channel and a gated ion channel. The conclusion that the AQP1-associated cation current contributes to modulating CSF production resolves a lingering concern as to whether an aquaporin ionic conductance can have a physiologically relevant function.

Key words: CSF; cyclic nucleotide-gated channel; major intrinsic protein; atrial natriuretic peptide; patch-clamp electrophysiology; small interfering RNA

\section{Introduction}

Aquaporin-1 (AQP1) channels in the major intrinsic protein (MIP) family mediate water movement across membranes in the brain, kidney, vascular system, and other tissues (Agre et al., 1993; King and Agre, 1996). AQP1 is abundant in the choroid plexus, a tissue bordering brain ventricles that produces CSF by active $\mathrm{Na}^{+}$transport and concomitant water flux from blood to brain (Wright and Saito, 1986; Speake et al., 2001). Atrial natriuretic peptide (ANP) receptors in choroid plexus epithelia couple to guanylate cyclase, stimulating cGMP generation (Tsutsumi et al., 1987; Israel et al., 1988) and inhibiting CSF production (Steardo and Nathanson, 1987). AQP1 has been found to have a cGMP-gated cation channel function (Anthony et al., 2000; Saparov et al., 2001), but its physiological relevance has remained unclear. We confirmed ion channel function of AQP1 and tested

Received Feb. 4, 2006; revised June 13, 2006; accepted June 13, 2006

This work was supported by the Blanceflor Boncompagni-Ludovisi Foundation Fellowship (D.B.), the National Institutes of Health-National Institute of General Medical Sciences (A.J.Y.), and the Research to Prevent Blindness Foundation (W.D.S.). We thank Dr. D. Dulcis for assistance with image processing and A. Marble and E. Erbe for technical support.

Correspondence should be addressed to Dr. Andrea J. Yool, Department of Physiology, P.0. Box 245051, University of Arizona, Tucson, AZ 85724. E-mail: ayool@u.arizona.edu.

D. Boassa's present address: National Center for Microscopy and Imaging Research, University of California, San Diego, La Jolla, CA 92093.

D0I:10.1523/JNEUROSCI.0525-06.2006

Copyright $\odot 2006$ Society for Neuroscience $\quad$ 0270-6474/06/267811-09\$15.00/0 for possible physiological relevance for CSF production in rat choroid plexus primary cultures.

Although the ion channel function of AQP1 initially was questioned (Agre et al., 1997), the simplest interpretation of all the evidence now in hand is that AQP1 directly mediates a gated cationic current (Yool and Stamer, 2002). Other members of the aquaporin family such as AQP6 (Yasui et al., 1999; Liu et al., 2005) and Drosophila Big Brain (Yanochko and Yool, 2002, 2004) also function as ion channels when expressed in oocytes but differ in mechanisms of activation and ionic selectivities, ruling out a simple explanation as endogenous oocyte ion channels. The lens AQP0 protein shows ion channel function in reconstituted bilayers (Zampighi et al., 1985; Ehring et al., 1990, 1992), although a physiological role for the conductance in the eye remains to be determined.

Modulatory contributions from proteins in signaling complexes with AQP1 (Cowan et al., 2000; Abu-Hamdah et al., 2004; Kelly et al., 2005) seem likely given the tissue-specific variability in channel properties, a concept that might also apply to other aquaporins. Opening probabilities for cGMP-gated AQP1 ion channels expressed in oocytes or reconstituted in bilayers are exceptionally low (Saparov et al., 2001; Yool and Weinstein, 2002) and undetectable in AQP1-transfected HEK cells (Tsunoda et al., 2004). Differences among these studies suggested that AQP1 ion channel activity might depend on the expression sys- 
tem, perhaps involving differentially expressed unidentified factors. We hypothesized that the appropriate conditions for full functionality might best be seen for AQP1 expressed in a native tissue.

Results here confirm that natively expressed AQP1 is a cGMPgated ion channel activated by ANP and that activation decreases fluid transport across confluent choroid plexus in culture. Selective loss of the cGMP-stimulated cationic current after two methods of AQP1-small interfering RNA (siRNA) treatment confirms that the conductance cannot be attributed to other endogenous ion channels in the choroid plexus (Hung et al., 1993; Speake et al., 2001, 2004). Our data are the first to show ion channel function in a native aquaporin and suggest the promise that aquaporin ionic conductances have physiologically relevant functions in regulatory mechanisms of transmembrane fluid transport in brain and other tissues.

\section{Materials and Methods}

Primary culture. Anesthetized 5-d-old Sprague Dawley rats were decapitated. Dissected lateral and fourth ventricle choroid plexi were triturated in Hanks' solution with $0.25 \%$ trypsin. DMEM/Ham's F-12 (1:1) medium with $10 \%(\mathrm{v} / \mathrm{v})$ fetal bovine serum stopped enzyme activity; cells were filtered $(100 \mu \mathrm{m})$, centrifuged $\left(400 \mathrm{rpm} ; 15 \mathrm{~min}, 6^{\circ} \mathrm{C}\right)$, and resuspended in DMEM/Ham's F-12 (1:1) containing $10 \%(\mathrm{v} / \mathrm{v})$ fetal bovine serum, $4 \mathrm{~mm} \mathrm{~L}$-glutamine, $5 \mu \mathrm{g} / \mathrm{ml}$ insulin, $1.0 \mathrm{U} / \mathrm{ml}$ penicillin, and 0.1 $\mathrm{mg} / \mathrm{ml}$ streptomycin. Cells seeded on murine laminin $(20 \mu \mathrm{g} / \mathrm{ml})$ plates were maintained at $37^{\circ} \mathrm{C}$ in humidified $5 \% \mathrm{CO}_{2}$. Cytosine arabinoside $(20 \mu \mathrm{M})$ was applied through day 4 in culture. From day 5 , cells were maintained in DMEM/Ham's F-12 (1:1) medium (5\% v/v fetal bovine serum), refreshed every $2-3 \mathrm{~d}$. Culture supplies were from Invitrogen (Carlsbad, CA).

Immunocytochemistry. Brains rapidly frozen in OCT medium were cryostat sectioned $(17 \mu \mathrm{m})$, fixed ( $4 \%$ paraformaldehyde; $1 \mathrm{~h}$ ), washed in 50 mm glycine buffer, $\mathrm{pH} 7.4$, and blocked with $1 \%$ donkey serum in PBS ( $\mathrm{pH} 7.4,0.1 \%$ Triton X-100). The following primary antibodies were applied overnight: anti-AQP1 (rabbit polyclonal) (Stamer et al., 1995) at $400 \mathrm{ng} / \mathrm{ml}$; or anti-prealbumin (goat polyclonal; Santa Cruz Biotechnology, Santa Cruz, CA) at 1:250. Slides were washed in blocking solution and incubated $2 \mathrm{~h}$ with secondary antibodies: fluorescein-conjugated donkey anti-rabbit IgG (1:100); or Cy5-conjugated donkey anti-goat IgG (1:200) (Jackson ImmunoResearch, West Grove, PA). Negative controls omitted primary antibodies. Sections were washed, mounted in Dako (Carpinteria, CA) medium, and viewed by confocal microscopy. Cultured cells on laminin-coated glass coverslips were fixed in MEM/ HEPES, pH 7.0, containing 4\% sucrose and $4 \%$ paraformaldehyde, washed in PBS (pH 7.4; 0.05\% Triton X-100 and 5\% donkey serum), and incubated with primary antibodies (as described above). After primary incubation, the cell cultures were washed with buffer (three times, $5 \mathrm{~min}$ each) and incubated for $1 \mathrm{~h}$ at room temperature with secondary antibodies. For double-staining experiments, the secondary antibodies used were the same as described for cryostat sections. For transfected cells, the secondary biotin-labeled donkey anti-rabbit antibody was used at 1:500 (for $1 \mathrm{~h}$ at room temperature) and washed three times with PBS (as above), and the cells were incubated for $30 \mathrm{~min}$ with Alexafluor555/ streptavidin at 1:4000 in the dark at room temperature. Finally, the cells were washed in PBS solution, $\mathrm{pH}$ 7.4, and mounted for microscopic visualization.

Reverse transcriptase- PCR. Total RNA was isolated from primary choroid plexus cultures (Qiagen kit; Qiagen, Santa Clarita, CA). After DNase digestion, reverse transcription was done using $2 \mu \mathrm{g}$ of total RNA, $1 \mu \mathrm{g}$ of random primer, $0.2 \mu \mathrm{g}$ of oligodeoxythymidine primer, $40 \mathrm{U}$ of RNase inhibitor, and $50 \mathrm{U}$ of reverse transcriptase (Moloney murine leukemia virus; Boehringer Mannheim, Indianapolis, IN) in a $35 \mu$ l total volume $\left(37^{\circ} \mathrm{C}, 1 \mathrm{~h}\right)$. Reverse-transcribed cDNA was used for PCR amplification with sequence-specific primers. For AQP1, the sequences were as follows: sense 5' -CCGAATTCATGGCCAGCGAGTTCAAGAAGAA-3' (31-61 bp) and antisense 5'-CGGGGGTGTTATCCGGGGTGGGTCTTTT-
AGGTCAC-3' (663-697 bp), for a product of 669 bp. For cyclophilin, the sequences were as follows: sense 5'-GGGGAGAAAGGATTTGGCTA-3' and antisense 5'-GCCACTGTGGTCAGTGTCAT-3', for a product of 259 bp. Each PCR amplification (50 $\mu$ l final volume) contained $50 \mathrm{pmol}$ of each primer, $0.2 \mathrm{~mm}$ each of deoxynucleotides, and 2.5 $\mathrm{U}$ of TaqDNA polymerase (Promega, Madison, WI). The reactions were performed in a PerkinElmer (Wellesley, MA) 9600 thermocycler using the following program: denaturation $\left(94^{\circ} \mathrm{C}, 120 \mathrm{~s}\right)$, annealing $\left(60^{\circ} \mathrm{C}\right.$, $90 \mathrm{~s})$, and polymerization $\left(72^{\circ} \mathrm{C}, 120 \mathrm{~s}\right)$ for 35 cycles, ending with $5 \mathrm{~min}$ at $72^{\circ} \mathrm{C}$ and storage at $4^{\circ} \mathrm{C}$. For electrophoresis, $2 \mu \mathrm{l}$ of PCR products were run on a $2 \%$ agarose gel $(80 \mathrm{~V}, 2 \mathrm{~h})$ and stained with ethidium bromide.

siRNA synthesis and transfection. Two approaches were used for the RNA interference experiments. The first method used a mixture of siRNAs generated with the Dicer kit (Gene Therapy Systems, San Diego, CA). For this method, double-stranded RNA for AQP1 was synthesized in vitro with $\mathrm{T} 3$ and $\mathrm{T} 7 \mathrm{RNA}$ polymerases, from Bam HI and HindIIIlinearized human AQP1 cDNA (from P. Agre, Duke University, Durham, NC). As a control, a proprietary commercial mixture of siRNAs with "no significant similarity to any known gene sequences from mouse, rat or human" (Silencer Negative Control siRNA; Ambion, Austin, TX) was used. In the second method, sequence-specific siRNAs designated as AQP1-siRNA-a and AQP1-siRNA-b with matching scrambled controls were synthesized (Ambion) based on sequences demonstrated previously to selectively target AQP1 (Splinter et al., 2003).

The sequences used by Splinter et al. (2003) for AQP1 show no predicted cross-reactivity with other protein coding sequences in the choroid plexus; BLAST (Basic Local Alignment Search Tool) searches of the mammalian gene database with the targeted and scrambled sequences resulted in perfect matches exclusively for AQP1 for the sequence siRNA-a and predominantly for AQP1 for the sequence siRNA-b, with several related hits for partial homology with mouse TRAF-interacting protein. The two scrambled sequences showed partial matches predominantly with noncoding genomic DNA, with the exception of one hit for the scrambled-b sequence for partial homology with mouse vomeronasal 1 receptor. TRAF is a tumor necrosis receptor-associated factor (Rothe et al., 1994); TRAF6 is important in transcriptional regulation during CNS development in several specific brain regions not including telencephalon, thymus, and choroid plexus (Dickson et al., 2004). The vomeronasal organ receptors mediate detection of pheromones (Ryba and Tirindelli, 1997; Rodriguez et al., 2002; Halpern and Martinez-Marcos, 2003) but have not been described outside of the olfactory system, suggesting indirect effects of the scrambled siRNA sequence on the choroid plexus are unlikely.

For transfection, cells were plated on $35 \times 10 \times 12 \mathrm{~mm}$ laminincoated glass-bottom dishes. Between days 4 and 11 in culture, cells were transfected using siPORT-Amine (Ambion) to introduce a plasmid carrying the enhanced green fluorescent protein (eGFP) marker (pEGFPN1; 100 ng/250 $\mu$ l; BD Biosciences Clontech, Palo Alto, CA), either alone or with siRNAs (AQP1-siRNA or scrambled sequences). The cells were incubated with the transfection complex for $4-5 \mathrm{~h}$, then $1 \mathrm{ml}$ of normal growth medium without antibiotics was added to each dish. Electrophysiological and immunocytochemical experiments were performed 2-3 d after transfection.

Electrophysiological recordings. Patch-clamp experiments were performed in whole-cell and excised patch-clamp configurations. Extracellular solutions all contained (in mM) $1 \mathrm{CaCl}_{2}, 2 \mathrm{MgCl}_{2}, 10$ glucose, and 5 HEPES, pH 7.3, and in addition contained $140 \mathrm{NaCl}$ and $5 \mathrm{KCl}$ for the " $\mathrm{NaCl}$ saline" and $125 \mathrm{Cs}$-methanesulfonate and $20 \mathrm{CsCl}$ for the "CsMES saline." The intracellular (pipette) solutions all contained (in $\mathrm{mm}$ ) 2 $\mathrm{MgCl}_{2}, 10$ glucose, 5 HEPES, 0.5 EGTA, and $2 \mathrm{Na}_{2} \mathrm{ATP}, \mathrm{pH} 7.2$, and in addition contained $120 \mathrm{~K}$-gluconate and $20 \mathrm{KCl}$ for the "KGluc saline," $140 \mathrm{KCl}$ for the " $\mathrm{KCl}$ saline," 140 tetraethylammonium (TEA)-Cl for the "TEACl saline," $120 \mathrm{Na}$-gluconate and $20 \mathrm{NaCl}$ for the "Na Gluc saline," and $135 \mathrm{Cs}$-methanesulfonate and $5 \mathrm{CsCl}$ for the CsMES saline. Data were recorded (AxoPatch 200A; Molecular Devices, Foster City, CA) using Sylgard-coated pipettes (4-6 M $\Omega$ for whole-cell patches; 3-5 M $\Omega$ for excised patches). Data were filtered $(2 \mathrm{kHz})$, digitized $(10 \mathrm{kHz})$, and analyzed by pClamp 9 software (Molecular Devices). Whole-cell record- 

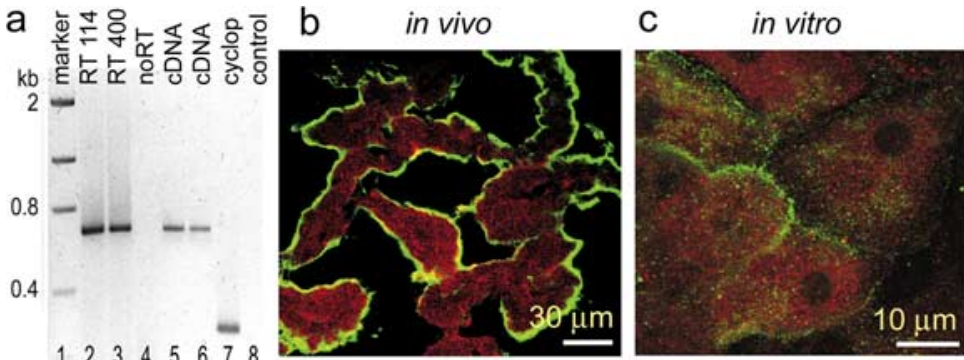

d
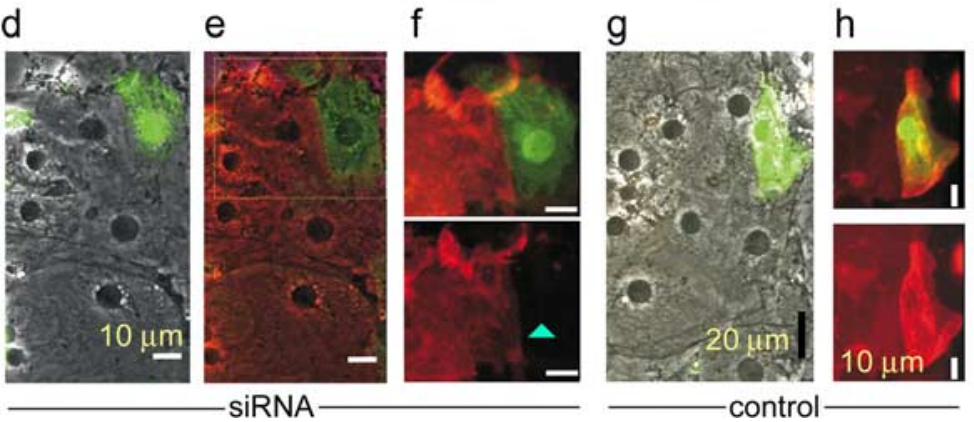

Figure 1. $A Q P 1$ expression in the choroid plexus in vivo and in vitro and knockdown by AQP1-siRNA treatment. $\boldsymbol{a}$, Reverse transcription-PCR confirmation of AQP1 expression in vitro. Lane 1, Low mass DNA marker; lanes 2-6, 8, PCR products for $A Q P 1$ using CDNA from reverse-transcribed (RT) RNA (lanes 2,3) at 114 and $400 \mathrm{ng}$, respectively, non-RT-RNA (lane 4; showing lack of genomic contamination), cloned AQP1 cDNA (lanes 5, 6), and no template (lane 8); lane 7, PCR product for cyclophilin (cyclop) using CDNA from reverse-transcribed RNA as a constitutively expressed control marker. $\boldsymbol{b}$, Cryostat-sectioned fourth ventricle rat choroid plexus immunostained for AQP1 (green) and prealbumin (red). c, Confocal image of primary cultures showing AQP1 (green) and prealbumin (red). $\boldsymbol{d}-\boldsymbol{f}$, AQP1-siRNA knockdown. $\boldsymbol{d}, \boldsymbol{e}$, Phase contrast superimposed with epifluorescent images $48 \mathrm{~h}$ after cotransfection of AQP1-mixed siRNA and eGFP marker (green), immunolabeled for AQP1 (red). $\boldsymbol{f}$, Fluorescence image showing AQP1 (red) is absent in the eGFP-siRNA-transfected cell (blue arrowhead). The top panel shows AQP1 and eGFP; the bottom panel is the same image for AQP1 alone. Scale bars, $10 \mu \mathrm{m} . \boldsymbol{g}-\boldsymbol{i}$, eGFP-transfected control. $\boldsymbol{g}, \boldsymbol{h}$, Control cells transfected with eGFP alone (48 h) show that both AQP1 (red) and eGFP (green) are present in the transfected cell. $\boldsymbol{h}$, Top, AQP1 and eGFP. Bottom, AQP1 alone. $\boldsymbol{i}$, Confocal image of a control eGFP-transfected cell (green) expressing AQP1 (red). A z-scan by confocal microscopy (bottom) along the indicated axis (white line; top) shows eGFP filling the cytoplasm of a cell in a full cross section (arrows), with AQP1 expression appropriately restricted to the apical surface.

ings were performed at $37^{\circ} \mathrm{C}$; single-channel recordings were at room temperature. Sodium nitroprusside (SNP; Sigma, St. Louis, MO) prepared fresh daily in sterile water was kept on ice, light protected. Data are mean \pm SEM unless stated otherwise. Statistical comparisons are noted in the text and legends.

Transepithelial flux measurements. Primary cultures of choroid plexus epithelia were grown $14 \mathrm{~d}$ in vitro on porous $0.4 \mu \mathrm{m}$ polycarbonate membranes (12-mm-diameter transwell plates; Costar, Cambridge, MA), using conditions as described for primary cultures above. One day before the flux assays, cells were fed with reduced-serum media [DMEM/ Ham's F-12 (1:1) supplemented with $0.5 \%(\mathrm{v} / \mathrm{v})$ fetal bovine serum]. Confluence of monolayers was assessed by net transepithelial electrical resistances (TEERs) $\geq 50 \mathrm{Ohm} \mathrm{cm}^{2}$ (Zheng et al., 1998), measured using a TEER measurement chamber (ENDOHM-24; World Precision Instruments, Sarasota, FL) in conjunction with a volt-ohmmeter (EVOM; World Precision Instruments). After aspiration of media from apical and basolateral compartments of transwell plates, fluid transport assays began by adding $4000 \mu \mathrm{l}$ of isotonic media [DMEM/Ham's F-12 (1:1)] to the lower chamber (basolateral) and $50 \mu$ l to the upper chamber (apical). Fluid transport was measured at $2 \mathrm{~h}$ intervals as the volume of fluid accumulated against a hydrostatic head in the apical chamber, determined by analytical balance. Net fluid accumulation at the apical side was monitored before and after treatment with $4.5 \mu \mathrm{M}$ ANP (applied basolaterally), in the presence and absence of $500 \mu \mathrm{M} \mathrm{Cd}^{2+}$ (applied apically).

\section{Results}

AQP1 is abundantly expressed in the choroid plexus in vivo and in vitro

In primary cultures of the choroid plexus isolated from postnatal day 5 rats, expression of AQP1 mRNA was confirmed by reverse top row:

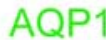
prealbum

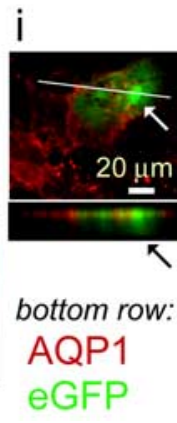

transcription (RT)-PCR amplification (Fig. 1a). AQP1 protein is abundantly expressed in rat choroid plexus cells in vivo and in vitro, as detected by immunocytochemistry (Fig. 1b,c) with AQP1-specific polyclonal antibodies recognizing the C-terminal domain (Stamer et al., 1995). Coimmunolabeling with antibodies against prealbumin provided a specific marker for choroid plexus cells (Aleshire et al., 1983).

Transfection of cultured choroid plexus cells with siRNA against AQP1 dramatically decreased expression of AQP1 protein. siRNA-transfected cells were identified by cotransfection with a plasmid vector carrying eGFP (Fig. $1 d-f$ ). Control transfection of choroid plexus cells with the eGFP plasmid alone did not alter the expression of AQP1 protein (Fig. 1 $g, h$ ). These data demonstrated that siRNA against AQP1 effectively knocked down protein expression in choroid plexus cells, confirming the molecular identity of the signal detected by RT-PCR and immunocytochemistry, as well as providing a useful tool for assessing the role of AQP1 in mediating cGMP-induced ionic currents (see below). The correct targeting of AQP1 to the apical membrane was confirmed for cultured choroid plexus cells using z-scanning confocal microscopy of control eGFP-transfected cells (Fig. 1i). The cytoplasmic eGFP fills the cell, whereas the signal for AQP1 is limited to the apical side of the cell.

\section{Properties of SNP-induced ionic currents in choroid plexus cells}

Selective activation of ionic current in cultured choroid plexus cells was recorded by whole-cell patch clamp after bath application of SNP, a nitric oxide donor that catalyzes the synthesis of intracellular cGMP. Endogenous $\mathrm{K}^{+}$and $\mathrm{Cl}^{-}$currents known to be present in the choroid plexus (Garner and Brown, 1992; Kotera and Brown, 1994; Speake et al., 2001, 2002, 2004; Speake and Brown, 2004) were minimized by ionic substitution of $\mathrm{NaCl}$ and $\mathrm{KCl}$ with $\mathrm{Cs}$-methanesulfonate, resulting in a low initial conductance before application of cGMP agonists (Fig. 2a). A robust SNP-dependent $\mathrm{Cs}^{+}$current was activated in choroid plexus cells (Fig. $2 a-c$ ); the cationic current showed a linear voltage-current relationship and block by external $\mathrm{Cd}^{2+}$, demonstrating properties comparable to those described previously for cloned human AQP1 heterologously expressed in Xenopus oocytes (Anthony et al., 2000; Yool, 2002; Boassa and Yool, 2003).

Previous work demonstrated that AQP1 cationic channels expressed in oocytes are permeable to $\mathrm{Cs}^{+}, \mathrm{Na}^{+}, \mathrm{K}^{+}$, and, to a lesser extent, $\mathrm{TEA}^{+}$with no appreciable $\mathrm{Cl}^{-}$permeability (Yool et al., 1996). Ionic substitution in the bath and pipette salines showed that the cGMP-dependent current in the choroid plexus is a nonselective cationic conductance with comparable relative permeabilities, as determined by comparison of the reversal potential with predicted equilibrium potentials for $\mathrm{Cl}^{-}$channels and nonselective cation channels (Fig. $2 d$ ). Predicted cationic reversal potentials were calculated based on the quantitative relative permeability values defined 


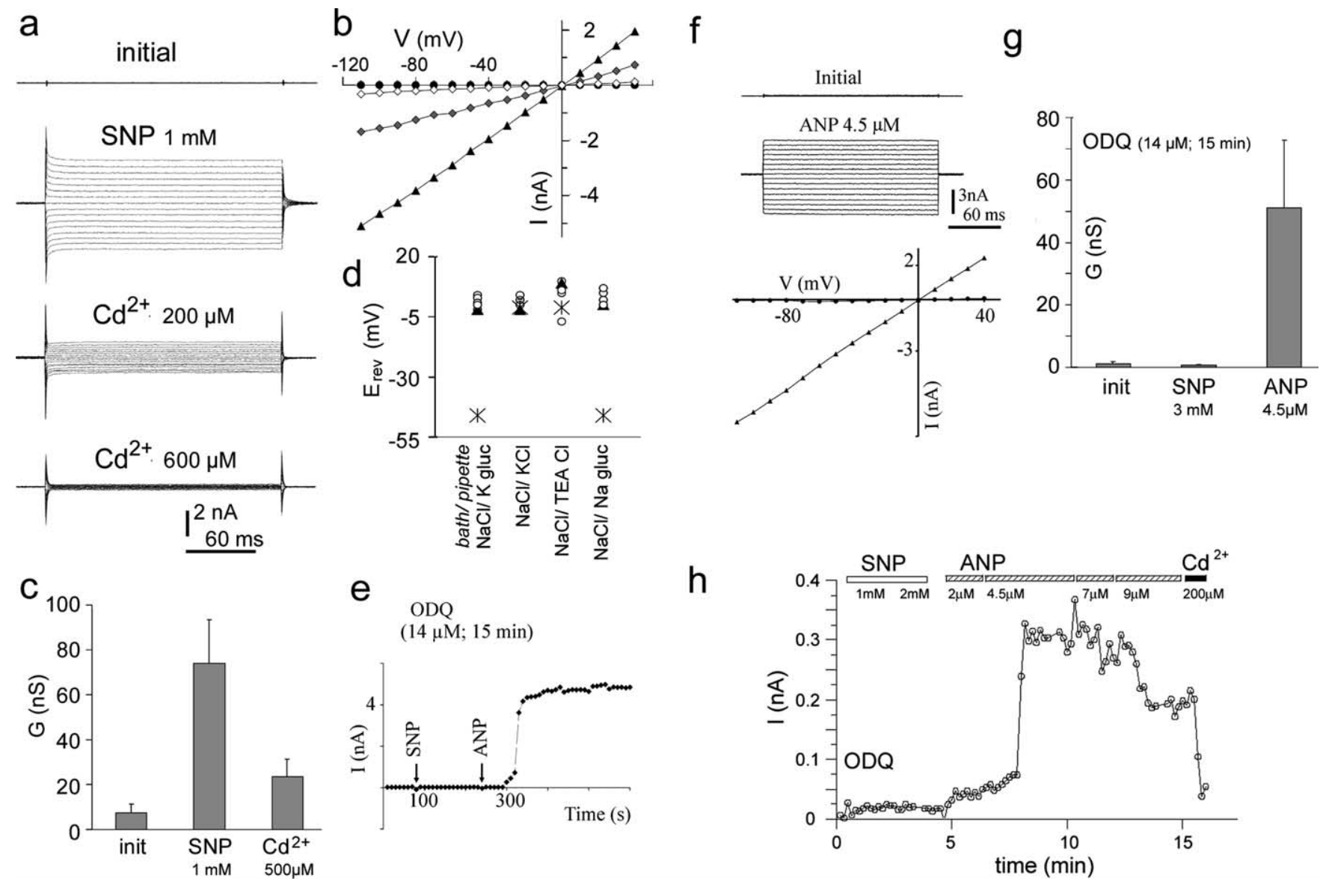

Figure 2. Properties of the CGMP-dependent cation current in cultured choroid plexus cells analyzed by whole-cell patch clamp. $\boldsymbol{a}$ - $\boldsymbol{c}$, lonic currents in Cs-methanesulfonate salines (pipette and bath) were activated by SNP and blocked by extracellular $\mathrm{Cd}^{2+}$. $\boldsymbol{a}$, Traces of currents recorded in a cell before SNP (initial), after a bolus application of SNP, and after subsequent additions of $\mathrm{Cd}{ }^{2+}$ to the bath saline. Concentrations are estimated final values. Voltage steps are +40 to -110 , from a $-30 \mathrm{mV}$ holding potential. $\boldsymbol{b}$, Current-voltage relationship for the cell shown in $\boldsymbol{a}$. c, Summary of the mean amplitude of the initial conductance (init) and the SNP-induced conductances before and after block by $\mathrm{Cd}^{2+}(n=5$ each). $\boldsymbol{d}$, Monovalent cation selectivity determined by the measured reversal potentials, $E_{\mathrm{rev}}$, f SNP-induced currents $\left(n=6\right.$ each) in various ion-substituted salines (circle) compared with calculated equilibrium potentials for $\mathrm{Cl}^{-}$(asterisk) and nonselective cation (triangle) conductances. $\boldsymbol{e}$, Block of the response to SNP but not to ANP by the soluble guanylate cyclase inhibitor ODQ (14 $\mu \mathrm{M} ; 15 \mathrm{~min}) . \boldsymbol{f}, \boldsymbol{h}$, lonic currents in Cs ${ }^{+}$salines activated by ANP. $\boldsymbol{f}$, ANP-dependent activation of a voltage-insensitive conductance comparable to that seen with SNP. Voltage steps were +40 to -110 from a holding potential of $-30 \mathrm{mV}$. $\boldsymbol{g}$, Summary histogram of the mean whole-cell conductances measured after preincubation with $\mathrm{ODQ}$ for initial recordings (init), and after treatment with SNP or ANP ( $n=5$ per treatment group). $\boldsymbol{h}$, Current amplitude at $+40 \mathrm{mV}$ measured by brief pulses from a holding potential of $-30 \mathrm{mV}$ every $10 \mathrm{~s}$. SNP, ANP, and Cd were applied as boluses over times indicated by bars, with estimated final concentrations shown. ODQ preincubation prevented the response to SNP but not ANP. The highest dose of ANP appeared to decrease current amplitude, perhaps reflecting desensitization. The current was blocked by $\mathrm{Cd}^{2+}$.

for AQP1 channels expressed in oocytes (Yool et al., 1996) and superimposed closely with the measured values in the choroid plexus.

The activation of ionic conductance in response to SNP was blocked effectively by the soluble guanylate cyclase inhibitor $1 \mathrm{H}$ $[1,2,4]$ oxadiazolo[4,3-a] quinoxalin-1-one (ODQ). Conversely, ODQ did not affect the conductance response to ANP, which activates an endogenous ODQ-insensitive receptor guanylate cyclase present in the choroid plexus (Fig. 2e). Thus, the SNPstimulated ionic conductance is induced by generation of cGMP rather than by chemical modifications such as $S$-nitrosylation (Ahern et al., 2002). It is noteworthy that the cGMP-dependent conductance can be stimulated by an endogenous signaling pathway in the choroid plexus, a necessary feature of a potentially physiologically relevant response.

The conductance induced by ANP, recorded with $\mathrm{Cs}^{+}$bath and pipette salines, showed properties comparable to those seen for the response induced by SNP. The ANP-evoked current showed a low initial conductance and an agonist-dependent nonvoltage-sensitive current with a reversal potential consistent with cationic selectivity (Fig. 2f). The ANP response was not sensitive to the soluble guanylate cyclase inhibitor ODQ (Fig. $2 g$ ) and was blocked by $\mathrm{Cd}^{2+}(200 \mu \mathrm{M})$ (Fig. 2h).

Application of a cGMP agonist (8Br-cGMP) to the internal face of excised inside-out patches from choroid plexus cells resulted in the activation of a large-conductance channel (Fig. 3) measured in symmetrical $\mathrm{Cs}^{+}$salines (chord conductance, $166 \pm$ $3 \mathrm{pS}$; mean $\pm \mathrm{SD}, n=6$ patches). The large-conductance channel showed properties of unitary conductance, long open-channel events, and dependence on cGMP similar to those described previously for AQP1 channels in oocytes (Anthony et al., 2000) and was blocked reversibly by $500 \mu \mathrm{M} \mathrm{Cd}{ }^{2+}$ applied to the internal face of the patch. Two classes of small-conductance channels $(\sim 20$ and $50 \mathrm{pS})$ also were present in patches with and without $8 \mathrm{Br}$-cGMP. In summary, 4 of 11 inside-out patches and 2 of 4 outside patches showed the large-conductance AQP1-like channel activity. These data support the hypothesis that the novel ion channel in the choroid plexus is AQP1; however, molecular confirmation was needed to rule out the possibility that another endogenous choroid plexus ion channel by coincidence showed the same set of properties. 


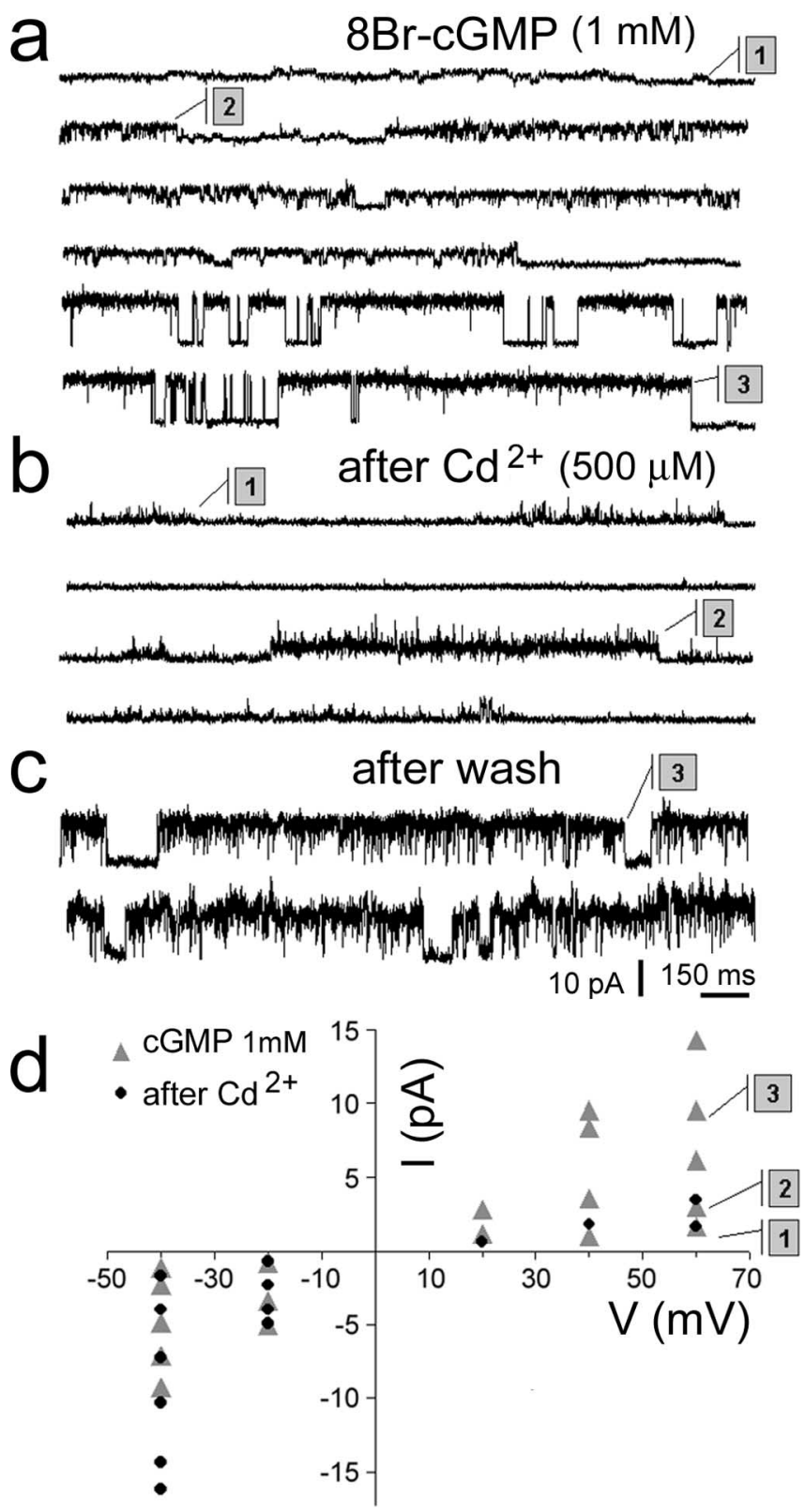

Figure 3. Excised inside-out patch recording from choroid plexus in vitro, illustrating activity of a $\mathrm{Cd}^{2+}$-sensitive AQP1-like channel. $\boldsymbol{a}$, Consecutive sweeps at $+60 \mathrm{mV}$ after application of $8 \mathrm{Br}-\mathrm{CGMP}(1 \mathrm{mM})$. The numbered boxes mark three classes of channels distinguished by unitary conductances. $\boldsymbol{b}$, Selective block of the large-conductance, AQP1-like channel by $\mathrm{Cd}^{2+}(500$ $\mu \mathrm{M}) . \boldsymbol{c}$, Recovery after washout of $\mathrm{Cd}^{2+}$. $\boldsymbol{d}$, Current amplitudes determined from all-points histograms. Unitary channel current levels are identified at $+60 \mathrm{mV}$ by numbered boxes; other amplitudes reflect combinations of channel events.

AQP1 knockdown by siRNA eliminates the cGMP-activated current

To determine whether the SNP-activated $\mathrm{Cd}^{2+}$-sensitive current is carried by native AQP1 ion channels in the choroid plexus, we used siRNAs to knock down levels of AQP1 protein expression. We used two different approaches: (1) transfecting the cells with a mixture of siRNAs generated by enzymatic digestion of AQP1 double-stranded RNA, with a commercially available mixed siRNAs as the control; and (2) transfecting with sequencedirected synthetic siRNAs with matched scrambled sequences as controls, characterized previously for AQP1 in cholangiocytes (Splinter et al., 2003).
In whole-cell patch recordings, eGFP-positive cells transfected with $15 \mathrm{~nm}$ of the AQP1-mixed siRNAs failed to show a $\mathrm{Cs}^{+}$current in response to SNP (Fig. 4a). Similarly, inclusion of $10 \mathrm{~mm} 8 \mathrm{Br}$-cGMP in the pipette saline failed to induce a Cs ${ }^{+}$ current in the AQP1-mixed siRNA-treated cells (Fig. 4b), consistent with the observation that AQP1 protein levels are reduced by the siRNA treatment (Fig. 1). In contrast, choroid plexus cells transfected with eGFP alone, or with eGFP and the controlsiRNA mixture, showed ionic conductances in response to SNP (Fig. 4a) and intracellular cGMP (Fig. 4b) that were not significantly different from the responses measured in nontransfected control cells (Fig. 4c). Two doses (15 and $60 \mathrm{nM}$ ) of control commercial siRNA mixture were tested. At a dose equal to that used to knock down AQP1 (15 nM), the control siRNA had no effect. At a fourfold excess, the control siRNA appeared to cause a modest decrease in the amplitude of the conductance response, suggesting high doses might have nonspecific effects. Nonetheless, the conductances measured for both groups of control siRNAtreated cells were significantly greater than that in the AQP1siRNA-treated group.

The sequence-targeted AQP1-siRNAs effectively suppressed the cGMP-induced $\mathrm{Cs}^{+}$currents in choroid plexus cells (Fig. $4 d$ ). The magnitude of the knockdown correlated with the dose of AQP1-siRNA and furthermore showed a differential efficacy between the two AQP1-siRNA sequences that matched published data (Splinter et al., 2003), in that AQP1-siRNA-b was more effective than AQP1-siRNA-a. The matching scrambled controlsiRNAs for the two AQP1 sequences (-a and -b) at the higher dose had no effect on the cGMP-induced conductance (Fig. $4 d$ ); the control groups were not significantly different from nontransfected cells.

Endogenous currents measured in the absence of cGMP stimulation in physiological saline conditions were not significantly affected by the AQP1-mixed siRNA treatment (Fig. 5). Voltage-dependent currents (primarily $\mathrm{K}^{+}$) were measured in whole-cell patch recordings using an on-line leak subtraction protocol. Total currents, measured as unsubtracted traces, comprised mainly $\mathrm{K}^{+}$and $\mathrm{Cl}^{-}$currents. The outward rectification of the voltage-sensitive current and the linear currentvoltage relationship of the total current were superimposed for the control and siRNA-treated cells, standardized to the maximum outward current at $+60 \mathrm{mV}$ for each cell (Fig. $5 b$ ). Reversal potentials were not affected by siRNA treatment, indicating that the relative contributions from the ensemble of background ion channels were not altered. The absolute values of the background total currents were comparable for control and siRNA-treated cells, demonstrating that the loss of the voltage-insensitive AQP1-like conductance after siRNA knockdown cannot be attributed to a parallel decrease in a background voltage-insensitive current (Fig. 5c). Although a small decrease in the mean current amplitude for the voltagesensitive component after siRNA treatment was seen, it was not significantly different from control. These data indicate that the introduction of the mixture of AQP1-siRNAs did not have any substantial effects on other general classes of ion channels found in the choroid plexus. These findings support the specificity of the siRNA knockdown and demonstrate that the cGMP-activated cationic current in the choroid plexus is mediated by AQP1. Contributions of AQP1 channels to the total currents were not observed in these recordings and were not expected in the absence of cGMP stimulation. 
AQP1 ion channel activation decreases net fluid transport in the choroid plexus To assess a possible contribution of AQP1 ion channel function to net fluid movement, primary cultures of choroid plexus epithelial cells were grown on $0.4 \mu \mathrm{m}$ polycarbonate membranes (12 $\mathrm{mm}$ diameter, Costar transwell plates) as confluent monolayers and selected based on attaining an electrical resistance equal or $>50$ $\mathrm{Ohm} \mathrm{cm}^{2}$. At day 14 in culture, isotonic medium was placed on both sides, with 4 $\mathrm{ml}$ in the lower chamber (basolateral) and $50 \mu \mathrm{l}$ in the upper chamber (apical). Net fluid flux was monitored before and after treatment with $4.5 \mu \mathrm{M}$ ANP applied basolaterally, in the presence and absence of $500 \mu \mathrm{M} \mathrm{Cd}{ }^{2+}$ applied apically (Fig. 6). Appropriate polarity of the epithelial layer was confirmed by z-scanning confocal microscopy (Fig. 1i) showing AQP1 was limited to the apical membrane (upper) side of the cultured cell layer. Fluid transport in the choroid plexus epithelium is a vectorial process, characterized by the net movement of salt and water from the basolateral to the apical side of the barrier. After a $2 \mathrm{~h}$ incubation without drug treatment, the volumes accumulated at the apical sides were measured (providing the baseline flow rate); volumes were measured again for the same filters after a $2 \mathrm{~h}$ incubation with ANP (with and without $\left.\mathrm{Cd}^{2+}\right)$. ANP decreased the flow rate to $58.5 \pm 13.4 \%$ of baseline ( $n=4$; mean \pm $\mathrm{SD})$, and this inhibitory effect was reversed by $\mathrm{Cd}^{2+}(85.5 \pm 14.9 \%$ of baseline; $n=4$; mean $\pm \mathrm{SD}$ ), which restored fluid movement to near baseline levels. Further characterization of AQP1 by knockdown with siRNA was not feasible, because the transfection efficiency in the primary choroid plexus cell cultures was, at best, $10 \%$ of the cells. Alternatively, we observed that downregulation of AQP1 protein after extended times in culture corresponded with a decreased effectiveness of ANP on transepithelial fluid transport. Immunocytochemical analyses showed that AQP1 consistently was expressed at high levels in apical membrane at 2 weeks in vitro but was substantially downregulated by 3 weeks in vitro. In corresponding transport studies of the choroid plexus at $23 \mathrm{~d}$ in vitro, there was no inhibitory effect of ANP on net fluid movement (data not shown).

\section{Discussion}

ANP receptors in the choroid plexus couple to guanylate cyclase, stimulating cGMP (Tsutsumi et al., 1987; Israel et al., 1988) and inhibiting CSF production (Steardo and Nathanson, 1987). We show that natively expressed AQP1 functions as a cGMP-gated ion channel and that the ionic conductance modulates fluid transport in the choroid plexus in a manner consistent with the observed effects in vivo. The similarities between AQP1 channel properties in the choroid plexus and the oocyte expression system, and the effective knockdown by AQP1-siRNAs, confirm that this conductance cannot be attributed to other channels
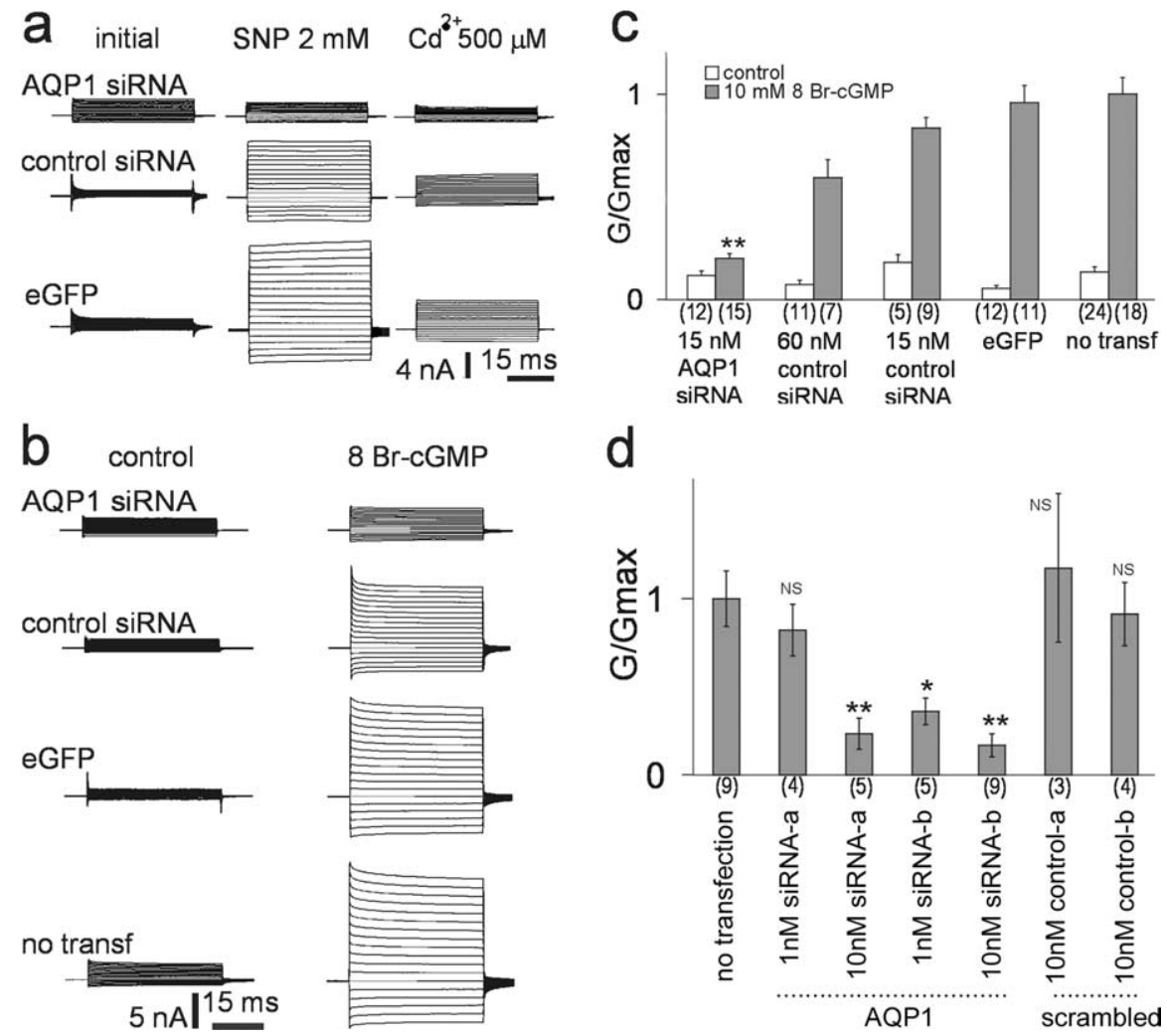

Figure 4. Loss of the CGMP-dependent cationic conductance by siRNA knockdown of AQP1 in the choroid plexus in vitro. $\boldsymbol{a}$, Whole-cell currents in (s-methanesulfonate saline before and after SNP and after subsequent application of $\mathrm{Cd}^{2+}$ in cells transfected with AQP1-mixed siRNA (15 nM), commercial control siRNA (60 nM), or eGFP alone. $\boldsymbol{b}$, Currents recorded without (left) and (1) 8Br-cGMP in the pipette from cells transfected with $15 \mathrm{~nm} \mathrm{AQP1-siRNA} \mathrm{mixture,} 60 \mathrm{~nm}$ control siRNA mixture, or eGFP results of treatments with $A Q P 1-$ mixed siRNAs and commercial control siRNA. Conductances $\left(G / G_{\text {max }}\right)$ were standardized to the currents with $10 \mathrm{mM} 8 \mathrm{Br}$-cGMP in the pipette saline were standardized to the mean $\mathrm{GMP}$-evoked conductance for all nontransfected cells within the same set of cultures. ${ }^{*} p<0.05$ and ${ }^{* *} p<0.006$, statistically significant differences from the nontransfected group (unpaired two-tailed Student's $t$ test). NS, Not significant; no transf, no transfection.

known to be expressed in the choroid plexus (Hung et al., 1993; Speake et al., 2001, 2004).

Aquaporins have four water-selective pores, one in each subunit (Murata et al., 2000; Sui et al., 2001). In AQP1, the ion-conducting pore has been suggested to reside at the tetrameric center (Yool and Weinstein, 2002). The bacterial glycerol facilitator (GlpF), although not known as an ion channel, has ion binding sites in its central cavity that implicate this domain as a candidate ion pore in other ion channel aquaporins (Fu et al., 2000). Molecular dynamic modeling predicts that $\mathrm{Na}^{+}$ions can, in theory, be pulled through the AQP1 central pore by a driving force (Yu et al., in press), whereas the individual subunit water pores do not allow ion permeation. Pharmacological data show that the AQP1 water and ion pathways are distinct; water permeability is blocked by TEA ${ }^{+}$and not $\mathrm{Cd}^{2+}$ (Brooks et al., 2000; Yool et al., 2002), whereas the ionic conductance is blocked by $\mathrm{Cd}^{2+}$ but not TEA (Yool, 2002). An expanding role for aquaporins is becoming evident (Yool and Stamer, 2004). Ion channel function has been demonstrated for AQP0 (Zampighi et al., 1985; Ehring et al., 1990, 1992), AQP1 (Anthony et al., 2000; Boassa and Yool, 2003), AQP6 (Yasui et al., 1999), and a related MIP channel known as Big Brain (Yanochko and Yool, 2002, 2004) that is essential in early nervous system development in Drosophila. 


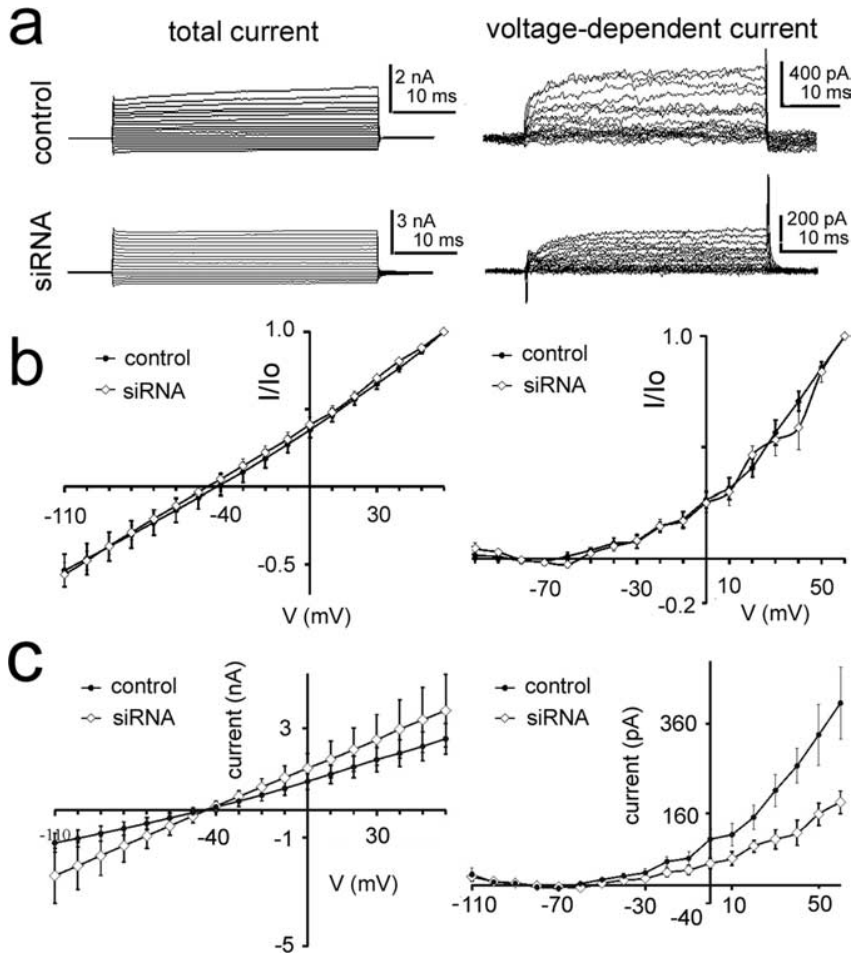

Figure 5. Lack of appreciable effects of AQP1-siRNA treatment on endogenous background ion currents in the choroid plexus, measured with physiological salines in the absence of cGMP stimulation. $\boldsymbol{a}$, Comparison of traces of ionic currents from choroid plexus cells that were untreated (control; top row) or transfected with $15 \mathrm{~nm} \mathrm{AQP1-mixed} \mathrm{siRNA} \mathrm{(bottom} \mathrm{row).} \mathrm{Currents}$ were measured without leak subtraction (total currents) and with an on-line P/4 leak subtraction protocol (voltage-sensitive currents), with $\mathrm{NaCl}$ bath saline and $\mathrm{K}$-gluconate pipette saline. $\boldsymbol{b}$, Averaged current-voltage relationships compiled for all cells tested in the two treatment groups, with current amplitudes standardized to the maximal outward current amplitude measured at $+60 \mathrm{mV}$, show no differences in rectification and reversal potentials. $c$, Data from $\boldsymbol{b}$ plotted as absolute rather than standardized amplitudes show no significant differences in mean current amplitudes between the control and siRNA treatment groups. Control group, $n=$ $13-14 ;$ AQP1-siRNA-treated group, $n=6$.

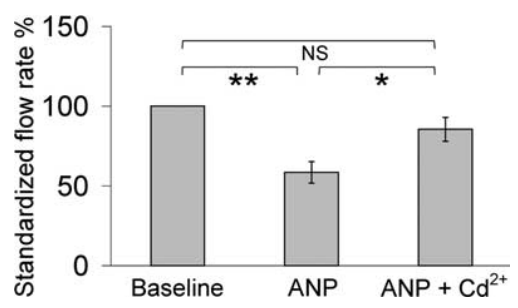

Figure 6. Net fluid transport assay in confluent monolayers before and after treatment with $4.5 \mu \mathrm{M}$ ANP, with and without $500 \mu \mathrm{M} \mathrm{Cd}^{2+}$ in the apical solution. The baseline rate defined as $100 \%$ indicates the net fluid flow rate in the monolayer culture before treatment with ANP; baseline flow rates averaged $50 \mu \mathrm{l} / \mathrm{h}$ and ranged from 35 to $117 \mu \mathrm{l} / \mathrm{h}$ for different preparations. Data for flow rates after treatments were standardized as a percentage of the corresponding baseline rate in the same monolayer culture. ${ }^{*} p<0.05$ and ${ }^{* *} p<0.001$, statistically significant differences (unpaired two-tailed Student's $t$ test). NS, Nonsignificant. ANP, $n=4$; ANP $+\mathrm{Cd}^{2+}, n=4$. Data are mean \pm SD.

Over the past decade, uncertainty in the AQP field has moved from an initial controversy about whether AQP1 is an ion channel (Agre et al., 1997) to whether or not the ion channel function can serve any meaningful contribution. The observation that AQP1 can serve as a cGMP-gated ion channel (Anthony et al., 2000; Boassa and Yool, 2002, 2003) has been confirmed independently by reconstitution in bilayers (Saparov et al., 2001), but the activity was suggested to be an artifact (i.e., misfolding of the
AQP1 channel protein to produce a gain of function as a cGMPgated cation-selective channel). The basis for uncertain functional relevance stems from the low numbers of AQP1 ion channels found to be active in expression systems. In oocytes, the cGMP-activated current typically ranges 5-10 $\mu \mathrm{A}$ at $+40 \mathrm{mV}$ from $1 \mathrm{ng}$ of AQP1 RNA injected, a respectable level compared with other ion channels. However, using the parallel water permeability of the channel, it is possible to estimate the total number of AQP1 channels in the oocyte, which outstrips the number of ion channels by $>50,000$-fold (Yool and Weinstein, 2002). When reconstituted in bilayers, the proportion of available ion channels is estimated at one per million (Saparov et al., 2001); ion channel activity was undetectable in AQP1-transfected HEK cells (Tsunoda et al., 2004). In lieu of explanation as an accident, these differences could suggest that AQP1 ion channel activity is sensitive to regulatory mechanisms or interactions that vary with the expression system.

What proportion of AQP1 channels in the choroid plexus might contribute to the ionic conductance? A rough estimate is possible using fluid transport and ionic conductance data. A whole-cell cGMP-dependent conductance of $\sim 100 \mathrm{nS}$ and a single-channel conductance of $166 \mathrm{pS}$ puts the number of active AQP1 ion channels at $\sim 700$ per cell (or more if the open probability is $<1$ ). To calculate water-channel number, the area of the $10^{8} \mu \mathrm{m}^{2}$ filter covered by confluent choroid plexus cells $(\sim 200$ $\mu \mathrm{m}^{2}$ each) corresponds to $\sim 5 \times 10^{5}$ cells per filter. The mean net fluid transport rate per filter was $50 \mu \mathrm{l} / \mathrm{h}$, or $\sim 10^{-4} \mu \mathrm{l} / \mathrm{h}$ cell. The AQP1 unitary water permeability is $10^{-13} \mathrm{~cm}^{3} / \mathrm{s}$ (Zeidel et al., 1992), or $10^{-7} \mu \mathrm{l} / \mathrm{h}$. Thus, the numbers of water pores per cell would be $\sim 1000$ and of tetramers would be $\sim 250$, no doubt an underestimate because total water flux must exceed the net fluid accumulation. If total water flux is 10 -fold greater than the measured net, the ratio of AQP1 ion channels to water channels would be $\sim 1: 10$. However, it is equally reasonable that the ratio might be $1: 100$ or $1: 1000$. An important caveat is that the real number of AQP1 channels per cell remains to be measured. If the level of AQP1 expression in the highly water-permeable kidney proximal tubule $\left(4 \times 10^{4}\right.$ per $\left.\mu \mathrm{m}^{2}\right)$ (Maeda et al., 1995) is an example of a maximum case, by analogy the estimated number of AQP1 tetramers per choroid plexus cell could be as high as $\sim 10^{7}$, which would yield an ion-to-ion channel ratio of $\sim 1: 10,000$. Any of these outcomes suggests that the availability of AQP1 to function as an ion channel is increased in the native choroid plexus environment compared with other preparations studied thus far. Precedent for the idea that a majority of channels can be in an inactive mode comes from quantitative analysis of the epithelial $\mathrm{Na}^{+}$channel ENaC; open-channel probability calculations were found to be one order of magnitude lower when referenced to the total population of $\mathrm{ENaC}$ channels, as opposed to assessment only of the electrically active subpopulation (Firsov et al., 1996). The difference for AQP1 is that the electrically silent channels have a known function as water pores, whereas the purpose of silent modes in other classes of ion channels is not equally obvious.

Tissue-specific control of AQP1 ion channel availability is logical given differences in the functional goals of organs; not all tissues in which AQP1 is highly expressed would benefit from the presence of a large-conductance cationic current. For example, calculations from proximal tubule model suggested that a trace population of active AQP1 ion channels (equivalent to that seen in the oocyte expression system) would be sufficient to measurably influence $\mathrm{Na}^{+}$reabsorption (Yool and Weinstein, 2002). Thus, the water-to-ion channel ratio of AQP1 might be a target of 
convergent control mechanisms, influenced by lipid environment, posttranslational modifications, cytoskeletal associations, or protein-protein interactions with molecules such as EphB2 tyrosine receptor kinase, anion transporters, and others (Cowan et al., 2000). Membrane environment and protein interactions govern properties of other ion channels (Konstas et al., 2003; Guggino, 2004; Kimura et al., 2004; Lin et al., 2004; Romanenko et al., 2004; Schreiber et al., 2004; Sorgen et al., 2004; Yanochko and Yool, 2004; Li and Naren, 2005; Song et al., 2005; Wang et al., 2005; Deval et al., 2006).

Ion channels and water channels are distinguished by their substrate specificity. An intriguing combination is seen in AQP1. In future work, it will be interesting to consider how depolarization, localized gradients of $\mathrm{Na}^{+}$at the water channel vestibules, back-leak of $\mathrm{Na}^{+}$, or other mechanisms involving activated AQP1 ion channels might contribute to the observed decrease in the net transport of fluid across the choroid plexus barrier in response to ANP. In the choroid plexus, unlike most epithelial cells, the $\mathrm{Na}^{+}-\mathrm{K}^{+}$-ATPase transporter is located in the apical membrane (Masuzawa et al., 1984) and provides the driving force for fluid secretion into the ventricle. Elevation of cGMP causes inhibition of $\mathrm{Na}^{+}-\mathrm{K}^{+}$-ATPase (Ellis et al., 2000), providing a logical mechanism for achieving decreased CSF production by downregulation of $\mathrm{Na}^{+}$active transport. Our data suggest cGMP-activated AQP1 ion channels also contribute to the regulatory response, because block of the $\mathrm{AQP} 1$ ionic conductance with $\mathrm{Cd}^{2+}$ reverses the inhibitory effect on ANP on fluid transport. This effect is opposite to what would be expected from $\mathrm{Cd}^{2+}$ block of the $\mathrm{Na}^{+}-\mathrm{K}^{+}$-ATPase pump, which should further suppress CSF production rather than restore it.

Pathologies and injuries associated with an imbalance between production and removal of CSF currently are limited in treatment options such as systemic diuretics or physical shunting. Recognition of AQP1 as a regulated multifunctional channel suggests it is a potential therapeutic target for pathological conditions involving altered fluid homeostasis (edema, hydrocephalus, pseudotumor cerebri, glaucoma, and others) and toxicity. The kidney proximal tubule and choroid plexus both express high levels of AQP1 and, coincidentally, are targets of $\mathrm{Cd}^{2+}$ toxicity (Valois and Webster, 1989; Thevenod, 2003). Expanding our understanding of mechanisms for the selective activation and block of aquaporin channels and their role in transmembrane signaling and transport are areas of compelling interest for advances in research and medicine.

\section{References}

Abu-Hamdah R, Cho WJ, Cho SJ, Jeremic A, Kelly M, Ilie AE, Jena BP (2004) Regulation of the water channel aquaporin-1: isolation and reconstitution of the regulatory complex. Cell Biol Int 28:7-17.

Agre P, Preston GM, Smith BL, Jung JS, Raina S, Moon C, Guggino WB, Nielsen S (1993) Aquaporin CHIP: the archetypal molecular water channel. Am J Physiol 265:F463-F476.

Agre P, Lee MD, Devidas S, Guggino WB (1997) Aquaporins and ion conductance. Science 275:1490; author reply 1492.

Ahern GP, Klyachko VA, Jackson MB (2002) cGMP and S-nitrosylation: two routes for modulation of neuronal excitability by NO. Trends Neurosci 25:510-517.

Aleshire SL, Bradley CA, Richardson LD, Parl FF (1983) Localization of human prealbumin in choroid plexus epithelium. J Histochem Cytochem 31:608-612.

Anthony TL, Brooks HL, Boassa D, Leonov S, Yanochko GM, Regan JW, Yool AJ (2000) Cloned human aquaporin-1 is a cyclic GMP-gated ion channel. Mol Pharmacol 57:576-588.

Boassa D, Yool AJ (2002) A fascinating tail: cyclic GMP activation of aquaporin-1 ion channels. Trends Pharmacol Sci 23:558-562.

Boassa D, Yool AJ (2003) Single amino acids in the carboxyl terminal do- main of aquaporin-1 contribute to cGMP-dependent ion channel activation. BMC Physiol 3:12.

Brooks HL, Regan JW, Yool AJ (2000) Inhibition of aquaporin-1 water permeability by tetraethylammonium: involvement of the loop E pore region. Mol Pharmacol 57:1021-1026.

Cowan CA, Yokoyama N, Bianchi LM, Henkemeyer M, Fritzsch B (2000) EphB2 guides axons at the midline and is necessary for normal vestibular function. Neuron 26:417-430.

Deval E, Friend V, Thirant C, Salinas M, Jodar M, Lazdunski M, Lingueglia E (2006) Regulation of sensory neuron-specific acid-sensing ion channel 3 by the adaptor protein $\mathrm{Na}+/ \mathrm{H}+$ exchanger regulatory factor-1. J Biol Chem 281:1796-1807.

Dickson KM, Bhakar AL, Barker PA (2004) TRAF6-dependent NF-kB transcriptional activity during mouse development. Dev Dyn 231:122-127.

Ehring GR, Zampighi G, Horwitz J, Bok D, Hall JE (1990) Properties of channels reconstituted from the major intrinsic protein of lens fiber membranes. J Gen Physiol 96:631-664.

Ehring GR, Lagos N, Zampighi GA, Hall JE (1992) Phosphorylation modulates the voltage dependence of channels reconstituted from the major intrinsic protein of lens fiber membranes. J Membr Biol 126:75-88.

Ellis DZ, Nathanson JA, Sweadner KJ (2000) Carbachol inhibits $\mathrm{Na}^{+}-\mathrm{K}^{+}$ ATPase activity in choroid plexus via stimulation of the NO/cGMP pathway. Am J Physiol Cell Physiol 279:C1685-C1693.

Firsov D, Schild L, Gautschi I, Merillat AM, Schneeberger E, Rossier BC (1996) Cell surface expression of the epithelial Na channel and a mutant causing Liddle syndrome: a quantitative approach. Proc Natl Acad Sci USA 93:15370-15375.

Fu D, Libson A, Miercke LJ, Weitzman C, Nollert P, Krucinski J, Stroud RM (2000) Structure of a glycerol-conducting channel and the basis for its selectivity. Science 290:481-486.

Garner C, Brown PD (1992) Two types of chloride channel in the apical membrane of rat choroid plexus epithelial cells. Brain Res 591:137-145.

Guggino WB (2004) The cystic fibrosis transmembrane regulator forms macromolecular complexes with PDZ domain scaffold proteins. Proc Am Thorac Soc 1:28-32.

Halpern M, Martinez-Marcos A (2003) Structure and function of the vomeronasal system: an update. Prog Neurobiol 70:245-318.

Hung BC, Loo DD, Wright EM (1993) Regulation of mouse choroid plexus apical $\mathrm{Cl}^{-}$and $\mathrm{K}^{+}$channels by serotonin. Brain Res 617:285-295.

Israel A, Garrido MR, Barbella Y, Becemberg I (1988) Rat atrial natriuretic peptide (99-126) stimulates guanylate cyclase activity in rat subfornical organ and choroid plexus. Brain Res Bull 20:253-256.

Kelly ML, Abu-Hamdah R, Jeremic A, Cho SJ, Ilie AE, Jena BP (2005) Patch clamped single pancreatic zymogen granules: direct measurements of ion channel activities at the granule membrane. Pancreatology 5:443-449.

Kimura K, Kitano J, Nakajima Y, Nakanishi S (2004) Hyperpolarizationactivated, cyclic nucleotide-gated $\mathrm{HCN} 2$ cation channel forms a protein assembly with multiple neuronal scaffold proteins in distinct modes of protein-protein interaction. Genes Cells 9:631-640.

King LS, Agre P (1996) Pathophysiology of the aquaporin water channels. Annu Rev Physiol 58:619-648.

Konstas AA, Koch JP, Korbmacher C (2003) cAMP-dependent activation of CFTR inhibits the epithelial sodium channel (ENaC) without affecting its surface expression. Pflügers Arch 445:513-521.

Kotera T, Brown PD (1994) $\mathrm{Cl}^{-}$current activation in choroid plexus epithelial cells involves a $\mathrm{G}$ protein and protein kinase A. Am J Physiol 266:C536-C540.

Li C, Naren AP (2005) Macromolecular complexes of cystic fibrosis transmembrane conductance regulator and its interacting partners. Pharmacol Ther 108:208-223.

Lin Y, Skeberdis VA, Francesconi A, Bennett MV, Zukin RS (2004) Postsynaptic density protein-95 regulates NMDA channel gating and surface expression. J Neurosci 24:10138-10148.

Liu K, Kozono D, Kato Y, Agre P, Hazama A, Yasui M (2005) Conversion of aquaporin 6 from an anion channel to a water-selective channel by a single amino acid substitution. Proc Natl Acad Sci USA 102:2192-2197.

Maeda Y, Smith BL, Agre P, Knepper MA (1995) Quantification of Aquaporin-CHIP water channel protein in microdissected renal tubules by fluorescence-based ELISA. J Clin Invest 95:422-428.

Masuzawa T, Ohta T, Kawamura M, Nakahara N, Sato F (1984) Immunohistochemical localization of $\mathrm{Na}^{+}, \mathrm{K}^{+}$-ATPase in the choroid plexus. Brain Res 302:357-362. 
Murata K, Mitsuoka K, Hirai T, Walz T, Agre P, Heymann JB, Engel A, Fujiyoshi Y (2000) Structural determinants of water permeation through aquaporin-1. Nature 407:599-605.

Rodriguez I, Del Punta K, Rothman A, Ishii T, Mombaerts P (2002) Multiple new and isolated families within the mouse superfamily of V1r vomeronasal receptors. Nat Neurosci 5:134-140.

Romanenko VG, Fang Y, Byfield F, Travis AJ, Vandenberg CA, Rothblat GH, Levitan I (2004) Cholesterol sensitivity and lipid raft targeting of Kir2.1 channels. Biophys J 87:3850-3861.

Rothe M, Wong SC, Henzel WJ, Goeddel DV (1994) A novel family of putative signal transducers associated with the cytoplasmic domain of the 75 $\mathrm{kDa}$ tumor necrosis factor receptor. Cell 78:681-692.

Ryba NJ, Tirindelli R (1997) A new multigene family of putative pheromone receptors. Neuron 19:371-379.

Saparov SM, Kozono D, Rothe U, Agre P, Pohl P (2001) Water and ion permeation of aquaporin-1 in planar lipid bilayers. Major differences in structural determinants and stoichiometry. J Biol Chem 276:31515-31520.

Schreiber R, Boucherot A, Murle B, Sun J, Kunzelmann K (2004) Control of epithelial ion transport by $\mathrm{Cl}$ - and PDZ proteins. J Membr Biol 199:85-98.

Song X, Zhao Y, Narcisse L, Duffy H, Kress Y, Lee S, Brosnan CF (2005) Canonical transient receptor potential channel 4 (TRPC4) co-localizes with the scaffolding protein $\mathrm{ZO}-1$ in human fetal astrocytes in culture. Glia 49:418-429.

Sorgen PL, Duffy HS, Sahoo P, Coombs W, Delmar M, Spray DC (2004) Structural changes in the carboxyl terminus of the gap junction protein connexin43 indicates signaling between binding domains for c-Src and zonula occludens-1. J Biol Chem 279:54695-54701.

Speake T, Brown PD (2004) Ion channels in epithelial cells of the choroid plexus isolated from the lateral ventricle of rat brain. Brain Res 1005:60-66.

Speake T, Whitwell C, Kajita H, Majid A, Brown PD (2001) Mechanisms of CSF secretion by the choroid plexus. Microsc Res Tech 52:49-59.

Speake T, Kajita H, Smith CP, Brown PD (2002) Inward-rectifying anion channels are expressed in the epithelial cells of choroid plexus isolated from ClC-2 "knock-out” mice. J Physiol (Lond) 539:385-390.

Speake T, Kibble JD, Brown PD (2004) Kv1.1 and Kv1.3 channels contribute to the delayed-rectifying $\mathrm{K}+$ conductance in rat choroid plexus epithelial cells. Am J Physiol Cell Physiol 286:C611-C620.

Splinter PL, Masyuk AI, LaRusso NF (2003) Specific inhibition of AQP1 water channels in isolated rat intrahepatic bile duct units by small interfering RNAs. J Biol Chem 278:6268-6274.

Stamer WD, Seftor RE, Snyder RW, Regan JW (1995) Cultured human trabecular meshwork cells express aquaporin-1 water channels. Curr Eye Res 14:1095-1100.

Steardo L, Nathanson JA (1987) Brain barrier tissues: end organs for atriopeptins. Science 235:470-473.

Sui H, Han BG, Lee JK, Walian P, Jap BK (2001) Structural basis of waterspecific transport through the AQP1 water channel. Nature 414:872-878.

Thevenod F (2003) Nephrotoxicity and the proximal tubule. Insights from cadmium. Nephron Physiol 93:87-93.
Tsunoda SP, Wiesner B, Lorenz D, Rosenthal W, Pohl P (2004) Aquaporin-1, nothing but a water channel. J Biol Chem 279:11364-11367.

Tsutsumi K, Niwa M, Kawano T, Ibaragi M, Ozaki M, Mori K (1987) Atrial natriuretic polypeptides elevate the level of cyclic GMP in the rat choroid plexus. Neurosci Lett 79:174-178.

Valois AA, Webster WS (1989) The choroid plexus as a target site for cadmium toxicity following chronic exposure in the adult mouse: an ultrastructural study. Toxicology 55:193-205.

Wang T, Jiao Y, Montell C (2005) Dissecting independent channel and scaffolding roles of the Drosophila transient receptor potential channel. J Cell Biol 171:685-694.

Wright EM, Saito Y (1986) The choroid plexus as a route from blood to brain. Ann NY Acad Sci 481:214-220.

Yanochko GM, Yool AJ (2002) Regulated cationic channel function in $\mathrm{Xe}$ nopus oocytes expressing Drosophila big brain. J Neurosci 22:2530-2540.

Yanochko GM, Yool AJ (2004) Block by extracellular divalent cations of Drosophila big brain channels expressed in Xenopus oocytes. Biophys J 86:1470-1478.

Yasui M, Hazama A, Kwon TH, Nielsen S, Guggino WB, Agre P (1999) Rapid gating and anion permeability of an intracellular aquaporin. Nature 402:184-187.

Yool A, Stamer W (2002) Novel roles for aquaporins as gated ion channels. In: Molecular insights into ion channel biology in health and disease (Maue R, ed). Amsterdam: Elsevier Science, in press.

Yool A, Brokl O, Pannabecker T, Dantzler W, Stamer W (2002) Tetraethylammonium block of water flux in Aquaporin-1 channels expressed in kidney thin limbs of Henle's loop and a kidney-derived cell line. BMC Physiol 2:4.

Yool AJ (2002) Block by divalent cations of the cyclic-GMP-gated ionic conductance in human aquaporin-1 channels. Biophys J 2002:275a.

Yool AJ, Stamer WD (2004) Novel roles for aquaporins as gated ion channels. In: Molecular and molecular insights into ion channel biology (Maue RA, ed), pp 351-379. Amsterdam: Elsevier.

Yool AJ, Weinstein AM (2002) New roles for old holes: Ion channel function in aquaporin-1. News Physiol Sci 17:68-72.

Yool AJ, Stamer WD, Regan JW (1996) Forskolin stimulation of water and cation permeability in aquaporin 1 water channels. Science 273:1216-1218.

Yu J, Yool AJ, Schulten K, Tajkorshid E (2006) Molecular mechanism of gating and ion conductivity of a possible tetrameric pore in Aquaporin-1. Structure, in press.

Zampighi GA, Hall JE, Kreman M (1985) Purified lens junctional protein forms channels in planar lipid films. Proc Natl Acad Sci USA 82:8468-8472.

Zeidel ML, Ambudkar SV, Smith BL, Agre P (1992) Reconstitution of functional water channels in liposomes containing purified red cell CHIP28 protein. Biochemistry 31:7436-7440.

Zheng W, Zhao Q, Graziano JH (1998) Primary culture of choroidal epithelial cells: characterization of an in vitro model of blood-CSF barrier. In Vitro Cell Dev Biol Anim 34:40-45. 